http://dx.doi.org/10.12775/szhf.2017.049

\title{
Remo Bodei, O życiu rzeczy, przeł. Alicja Bielak, Wydawnictwo Przypis, Łódź 2016, ss. 183
}

Niewiedza i strach to dwa strumienie napędzające ten sam młyn - młyn poznawczego paraliżu, intelektualnej inercji. Wiedział o tym Seneka, czemu dał wyraz, kierując do Lucyliusza takie słowa: „To, co - jak widzisz nieraz przytrafia się dzieciom, zdarza się również i nam, nieco większym dzieciom: gdy ludzi, których kochają, do których się przyzwyczaiły, z którymi się bawią, widzą ubranych w maski, boją się ich. Otóż należy zdjąć maski nie tylko ludziom, lecz i rzeczom, przywracając im ich właściwy wygląd”. Podobny cel stawiało sobie w historii wielu filozofów: w filozofii nowożytnej wybrzmiał on chyba najbardziej w myśli Hegla w jego dążeniu do pojednania ze sobą bytu i myślenia, zaś w czasach nam bliższym w myśli Husserla, którego filozoficzną ambicją było odtworzenie nierozerwalnego związku łączącego świadomość i rzeczy („Zu den Sachen selbst!”).

Napisana przed kilkoma laty przez współczesnego włoskiego filozofa Remo Bodei książka O życiu rzeczy [wł. La vita delle cose], dzięki przekładowi Alicji Bielak i Wydawnictwu Przypis, trafia obecnie do rąk polskiego czytelnika. Urodzony na Sardynii filozof nie prowadzi tu dialogu z wielkimi tradycjami filozoficznymi kontestującymi klasyczną metafizykę, która skupiała się na pojęciach, a nie na ich realnych desygnatach. Zdecydowanie nie aspiruje też do stworzenia pracy naukowej z zakresu ontologii. Ta stosunkowo niewielkich rozmiarów monografia ma nie tyle czytelnika przekonać, ile raczej zaintrygować, zachęcić do obdarzenia świata materialnego większą uwagą - w sposób radykalnie inny niż czynią to współcześni ludzie opętani konsumenckim szałem posiadania i używania jak największej liczby rzeczy. Towarzyszy temu pewien paradoks: otaczanie się dużą liczbą przedmiotów materialnych niekoniecznie oznacza świadomy z nimi kontakt (jakkolwiek enigmatycznie to brzmi). 
Już sam tytuł książki, O życiu rzeczy, wystawia czytelnika na intelektualną próbę. W jaki sposób „coś” z gruntu pozbawionego wszelkich cech witalnych i nieuczestniczącego w żadnych procesach życiowych (metabolizm, wzrost, rozmnażanie itp.) miałoby istnieć na sposób ludzi i zwierząt, względnie roślin - i partycypować w ich „życiu”? Nieprzypadkowo Bodei sięga po pojęcie należące raczej do języka biologii, a nie do terminu filozoficznego, do „istnienia” czy "egzystencji”. W ten sposób zamierza podkreślić zamiar, który mu przyświeca - ukazanie unikalnego statusu rzeczy i przypomnienie ich niegdysiejszej „świetności”.

Książka składa się z trzech części, które dzielą się na kilkustronicowe podrozdziały. Część pierwsza, opatrzona tytułem „Przedmioty i rzeczy”, jest zasadniczym rozdziałem książki, gdzie autor za pomocą erudycyjnej analizy filologicznej precyzyjnie rozróżnia i wyszczególnia to, co w języku potocznym często traktuje się synonimicznie: „rzeczy” i „przedmioty”, zaznaczając przy tym, że bliższe jest mu pojmowanie świata materialnego w kategoriach „rzeczy”. Decyzja ta jest nie bez znaczenia, gdyż wyznacza kierunek dalszych rozważań.

Otóż włoskie słowo oggetto (odpowiednik polskiego „przedmiotu”) wywodzi się bezpośrednio z terminu objectum, ukutego dopiero przez średniowieczną filozofię scholastyczną, oznaczającego „,coś, co jest naprzeciw”. Słowo to ma zdaniem Bodei konfrontatywne konotacje, wprowadzające pewne poznawcze napięcie między podmiotem a przedmiotem, który jawi się jako przeszkoda, zastrzeżenie czy wątpliwość (stąd „obiekcja”). Jest to w opinii włoskiego filozofa walka z góry przegrana przez „byt” w rozumieniu „przedmiotu" - skazanego odtąd na pastwę tego, co może jedynie domniemywać o nim podmiot uzurpujący sobie władzę nad światem materii.

Tymczasem Bodei przypomina, że istnieje inny termin na określenie tej kategorii bytów - mianowicie „rzecz” (wł. cosa), będąca włoskim odpowiednikiem greckiego terminu pragma, niemieckiego die Sache oraz łacińskiego res. Po pierwsze, termin ten jest o wiele bardziej pojemny (mieści w sobie także ludzi i idee). Po drugie, ,jest splotem zależności, w który czuję się włączony [...], ale nad którym nie chcę sprawować wyłącznej kontroli” (s. 34). Termin ten miałby zatem być bardziej adekwatny do opisywania złożoności świata materialnego, gdyż przywraca utraconą więź spajającą ludzi z rzeczami oraz odsyła do tego, co łączy (a nie jest „przeszkodą” jak objectum): do przestrzeni kolektywnej, debaty i deliberowania. Słowem - włoskiemu filozofowi najbliższy jest horyzont sensu roztaczany przez słowo res-publica, który 
najdobitniej unaocznia to, czym winien być świat przedmiotów w ludzkich społecznościach.

Antropolodzy i etnolodzy, jak na przykład Marcel Mauss czy Claude Lévi-Strauss, obserwując kultury pierwotne i zastanawiając się nad tym, jak bardzo rozpowszechniona jest wśród nich fetyszyzacja przedmiotów materialnych, doszli do wniosku, że człowiek dysponuje pewną nadwyżką znaczenia, którą następnie obdarza otaczające go obiekty. Jest to z konieczności związane z tym, że istota ludzka posiada język, który różnicuje i nadaje otoczeniu określoną strukturę. Fetyszyzm jest wpisany w ludzką naturę, i nawet jeśli dla współczesnego człowieka drewniany czy kamienny bożek nie ma już żadnej aury sensu, to fotografia czy część garderoby może być dla niego czymś o niebagatelnym znaczeniu .

Książka Remo Bodei jest swego rodzaju zachętą, by z jednej strony konsumpcjonizm i przesyt towarów, z drugiej zaś kultura nieprzywiązywania się do łatwo wymienialnych rzeczy i produktów jednorazowego użytku nie wyrugowały z ludzkiej natury sensotwórczej relacji, która wiąże człowieka ze światem materii. Włoski filozof namawia do przebudzenia ze snu przyzwyczajeń i dominacji warstwy funkcjonalnej nad symboliczną, zachęca, by rzeczom pozwolić ukazać się na nowo w świetle dnia wraz ze swoim nieprzebranym potencjałem tworzenia wciąż nowych znaczeń. Wiąże się z tym określony cel, który przyświeca Sardyńczykowi: „aby to zrozumieć [tj. fakt, że rzeczy posiadają nieskończony zakres znaczeniowy - D. W.], należy po pierwsze w analityczny sposób odtworzyć odpowiednie słownictwo, za pomocą którego można by pokazać nie tylko to, jak znaczenia symboliczne, poznawcze i afektywne osadzają się na rzeczach, lecz także dlaczego owe znaczenia nie stanowią jedynie zbędnych i zewnętrznych dodatków" (s. 23). Cel ten Bodei stara się konsekwentnie realizować poprzez poszukiwanie różnych kontekstów, przede wszystkim w filozofii, lecz także w literaturze i sztuce, które wspomniane znaczenia starają się z rzeczy wydobywać i eksponować.

Przewodnim tematem części drugiej „Otworzyć się na świat” jest fenomen konsumpcjonizmu. Autor bardziej niż na zdolności rzeczy do generowania nowych znaczeń i sensów skupia się tu na tych właściwościach rzeczy, które przypominają o tym, że ,jesteśmy [...] włączeni w swoisty splot relacji z przedmiotami nadającymi spójność naszej tożsamości” (s. 75). Starożytne papirusy, wiekowe pomniki, średniowieczne krucyfiksy - to wszystko składa się na tak zwaną kulturę materialną, bez której człowiek miałby utrudniony dostęp do rozumienia nie tylko społeczności, w której przyszło mu żyć, ale także samego siebie. Wszystko to, zdaje się mówić Bodei, może jednak ulec 
zmianie, gdyż w czasach współczesnych jak nigdy dotąd pojawiła się tendencja do banalizacji rzeczy, które za sprawą postępu technologicznego i ludzkiej ignorancji zaczęły na powrót wyradzać się $\mathrm{w}$ nic nieznaczące przedmioty. Akumulacja przedmiotów w czasach, gdy szeroki dostęp do przedmiotów (nie tylko dóbr użyteczności, ale też posiadających walory estetyczne) jest niemal powszechny, z jednej strony sprawia, że "piękno wystąpiło z brzegów" (s. 108), przestając być jedynie domeną świątyń i pałaców i stając się dostępne wszystkim, z drugiej zaś doprowadziła do swoistej „inflacji piękna”. Do utraty przez nie ich wartości - w znaczeniu nie tylko estetycznym, ale i aksjologicznym.

Między słowami wypełniającymi rozdział drugi przeziera nostalgia autora za społeczeństwem przedprzemysłowym i, jak sam to określa, „laryczną atmosferą domostwa" (s. 103), w którym każdy przedmiot był otaczany szacunkiem i niemal religijnym kultem. I choć czasy te bezpowrotnie minęły, to jednak autor podaje kilka strategii wspomagających proces przywracania rzeczom ich znaczenia. „Spośród wszystkich tych dróg - pisze Bodei - najbardziej obiecująca wydaje się ścieżka sztuki. Obrała ją też współczesna filozofia, uznając, że najlepiej doprowadzi ona do przywrócenia rzeczom tych znaczeń, której jako zbędne i marginalne zostały zatarte przez nawyk, osłabienie pamięci historycznej oraz naukowe uogólnienia" (s. 115-116). Rozwinięcie kwestii dotyczącej roli sztuki w przywracaniu utraconej więzi między człowiekiem a rzeczami zajmuje całą część trzecią pt. „Żywa natura”.

Zagadnienia tu poruszane skupiają się wokół sztuki - Bodei sięgnął do tej tradycji w malarstwie (jego rozważania ograniczają się głównie do tej formy sztuki), którą interesowały nie tyle sceny sakralne i mityczne, ile rodzajowe i codzienne, a zwłaszcza przedstawienia martwej natury. Jak stwierdza włoski filozof, ten rodzaj malarstwa w języku holenderskim określany terminem stilleven „oznacza nieruchomą (czy też niemą) naturę i odnosi się do przedstawienia ukazującego grupę rzeczy, które artysta postanowił uczynić treścią obrazu i dlatego wyrwał je z macierzystego kontekstu, w skład którego zwykle wchodzi człowiek [...]" (s. 133). Nie jest więc żadną tajemnicą, dlaczego właśnie autor sięgnął do tej tradycji: kontemplacja metaforycznych i alegorycznych dzieł mistrzów niderlandzkich jest przykładem tego, jak „oddać głos rzeczom” i pokazać, że nawet życie w kulturze instant może połączyć człowieka na nowo ze światem rzeczy i wzmocnić jego tożsamość, gdy tylko będzie kultywował pamięć o tym, że „rzeczy wytwarzają synapsy znaczeń, w których łączą się zarówno rozmaite fragmenty historii jednostkowych i zbiorowych, jak i rozmaite formy kultury z naturą". Przesłanie włoskiego 
filozofa nie ogranicza się jedynie do zaproszenia do częstszego odwiedzania galerii i muzeów, ale do przekonania w duchu Spinozy (do którego zresztą autor w tej części książki nierzadko nawiązuje), że głębsze poznanie rzeczy w ich jednostkowości oznacza także głębsze poznanie świata, Boga i nas samych.

Książka Remo Bodei, mimo że nie podejmuje wcale nowego wątku w filozoficznej dyskusji na temat statusu rzeczy i ich miejsca w świecie ludzi i nie daje żadnych oryginalnych i niespodziewanych rozwiązań, z powodu wielości poruszanych wątków, erudycyjności i świeżej formy i pełnego polotu języka jest bez wątpienia lekturą wartą polecenia. Nie jest to typowy podręcznik akademicki, nie jest to też typowa pozycja $\mathrm{z}$ zakresu literatury popularnonaukowej. Wielość poruszanych wątków, a także lekkość, z jaką ten nieznany dotąd w Polsce autor porusza się po zagadnieniach pozornie od siebie odległych (badania dwudziestowiecznych etnologów, współczesna moda, fenomenologia, współczesny przemysł, japońska kultura parzenia herbaty) niekiedy wprawia w zdumienie. Mając za sobą lekturę $O \dot{z} y c i u$ rzeczy trudno nie ulec przesłaniu autora, że „miłość do rzeczy”, współcześnie rozumiana raczej jako obsesyjne przywiązanie do gromadzonych przez lata przedmiotów, może mieć inny, bardziej pozytywny wymiar: nadający ludzkiej tożsamości spójność więzi, bez której człowiek „nie były tym, kim jest”.

Dawid Wincław

Uniwersytet Mikołaja Kopernika, Toruń, Polska e-mail:dwinclaw@doktorant.umk.pl 